\title{
Motivation in Learning English Language: a case Study at Vietnam National University, Hanoi
}

\author{
Huy Cuong Nguyen, PhD \\ The University of Szeged, Hungary
}

Doi: 10.19044/ejes.v6no1a4

URL:http://dx.doi.org/10.19044/ejes.v6no1a4

\begin{abstract}
In recent times, English has become the global language and plays an important role in order for people to communicate and fit into the real world. Learning and using English has become a necessary need of many people, particularly the young generation. Motivation is considered as one of the fundamental factors in successfully learning a language. This paper focuses on investigating the type and level of motivation in English language learning. The instrument of the study was adopted from Gardner's Attitude/Motivation Test Battery (AMTB). The participants in this study includes 371 first and second-year students of Vietnam National University, Hanoi - University of Engineering and Technology (VNU-UET). The collected data were summarized and analyzed by using SPSS software. The findings show that the students that participated in the study were highly motivated in English learning, and more instrumentally motivated. The study also examined some factors that influence motivation such as students' gender, the school year, the time students have spent in learning English, and parental ability in speaking English. The study shows that the school year and parental English ability had a significant influence on students' motivation in English language learning. The problems that the students face during the learning process was also discussed. Some recommendations were given to improve the students' motivation in English learning.
\end{abstract}

Keywords: Motivation, instrumental motivation, integrative motivation, language learning.

\section{Introduction}

Presently, English is the global language and it plays an important role in order for people to communicate and fit into the real world. Although spending at least three years of learning English language education, many Vietnamese high-school leavers are still not proficient in this language. This is the reason why most of the institutions in Vietnam have to provide further 
English language support for the first 2-years of higher education. However, the employers complain a lot about the level of English language proficiency among graduates. There are many factors responsible for low proficiency in English among vietnamese students. One of the factors might be attributed to the students motivation towards English language. This is because students' motivation has been extensively considered as an important factor which affects the rate and the success of foreign language learning (Ellis, 1994). McDonough (1983) also confirmed that "motivation of the students is one of the most important factors influencing their success or failure in learning the language".

The study aims to use one quantitative method to investigate the motivation of university students in Vietnam pertaining to the study of English as a foreign language, the English speaking people, and the students' future expectations about English. Furthermore, a better understanding of student's motivation may help English curriculum and instruction designers to build language learning and teaching programs which generate the motivation most conducive for more successful learners of English (Midraji, 2003).

\section{Background of the Study}

The VNU University of Engineering and Technology (VNU-UET) was founded by the decision of the Prime Minister of Vietnam as a member university of the Vietnam National University, Hanoi (VNU). The VNU-UET offers bachelor, master, and doctoral degree programs in engineering, technology, and management. As a leading university in engineering and technology in Vietnam, VNU-UET always tries to provide students with more opportunities to improve their English skills. In addition to the English skills the students have achieved in the high school education, most of the bachelor degree programs of VNU-UET provide students with 4 courses of general English (equally 20 credits) in the first 2-years of the programs. It is expected that the students of VNU-UET take the courses in English and use it as the medium of instruction. However, the students' progress in English skills is still not satisfactory. There are still many negative behaviors indicating that the students have low motivation to learn English as a foreign language.

The study on motivation to learn English based on the responses of the first and second-year undergraduate students at VNU-UET is expected to provide important information in determining the extent and type of their motivation to learn English. A better understanding about the motivation to learn English would help the university and English teachers work together to improve the language learning environment and to stimulate students' motivation. This would lead to better achievement in learning English as a foreign language for the first 2-years of undergraduate education and training. 


\section{Objectives of the Study}

This small-scale study was implemented to determine the motivational type and level of the first and second year undergraduate students at VNUUET, and to determine the factors that influence the students' motivation in learning English. The other objectives of this study are to find out the language difficulties that the students encountered during the learning process and to provide some recommendations for improving the students' motivation in learning English.

\section{Research Questions}

The following research questions addressed in this study are:

(a) What is the motivation for learning English as a foreign language by the students at VNU-UET?

(b) How does the students' background affect their motivation in learning English as a foreign language?

(c) What are the difficulties that students encounter during the learning process?

\section{Review of Literature}

\section{The Motivation for Learning a Foreign Language}

Motivation is a multifaceted concept that has been the subject of scholarly researches in different academic areas and no single available theory has yet captured its total complexity (Dörnyei, 2001). Gardner (2006) also confirmed that "motivation is a very complex phenomenon with many facets...thus it is not possible to give a simple definition." This is because the expression of motivation has been investigated differently by different perspectives. On the behavioral perspective, motivation is "quite simply the anticipation of reward" (Brown, 2000). Whereas the cognitive perspective views the term of motivation as being more related to the student's decisions, and the choices students make as to what experiences or goals they will approach or avoid, and the degree of effort they will exert in that respect. For the constructivists in their definition of motivation, they place further emphasis on the social context as well as the individual's decisions. Regardless of the differences in all the definitions of motivation given by the three different perspectives, the concept "needs" is emphasized, that is, "the fulfillment of needs is rewarding, requires choices, and in many cases must be interpreted in a social context” (Brown, 2000).

In terms of language learning, there are many definitions of motivation. Lightbown and Spada (1999) noted that motivation in second language learning is quite complicated to study. This can be explained in terms of two factors: students' communicative needs and their attitudes towards the second language community. In addition, Parsons, Hinson and Brown (2001) 
defined motivation as an important component or factor in the learning process. Learning and motivation have the same importance in order to achieve something. Learning helps students gain new knowledge and skills, and motivation pushes them or encourages them to go through the learning process.

Gardner (1983), in his socio-educational model, considered that motivation is perceived to be composed of three elements such as: effort, desire, and effect. The effort refers to the time the student spend on a foreign language learning and the drive of the student. The desire indicates how much the student wants to become proficient in the language, while the effect means the student's emotional reactions which is related to language learning.

\section{Types of Motivation for Learning a Foreign Language}

The type of motivation answers the question of why a person is learning a language. The motivation here refers to the goal of learning a language. Many different reasons for learning a language could be listed such as: to be able to speak with members of that language community, to get a job, to improve one's education, to be able to travel, to please their parents, to satisfy a language requirement, to gain social power, etc.

Harmer (1991) used the word "goal" to classify the motivation in language learning into two different types which include:

(a) Short-term goal: It means that students wish to succeed in doing something in the near future. For example, students who want to pass their examination or get a good grade/high scores.

(b) Long-term goal: It refers to a wish that students want to get a better job in the future and be able to communicate with people who use the language (the target language) that they learn.

Gardner (1985) shows it is possible to classify the reasons for language learning so that they reflect some ultimate aims. Once classified, various categories would appear best identified as orientations in order to keep conceptual clarity. Ellis (1986) discussed the need to classify the reasons for language learning when he put forward that "motivation in language learning can be defined in terms of the learner's overall goal or orientation." Brown (2000) decided that studies on the motivation of foreign language students rarely refer to a distinction between two kinds of motivation namely, instrumental motivation and integrative motivation. Gardner (1985) considered that an integrative orientation towards foreign language learning reflects "a sincere and personal interest in the people and culture represented by the other group", and an instrumental orientation emphasizes "the practical value and advantages of learning a new language.” The integrative orientation thus stresses an emotional involvement with other community, while the instrumental orientation does not. 
According to Saville-Troike (2006), the integrative motivation in foreign/second language learning was defined as the desire to be a part of recognized or important members of the community or the society that speaks the language. It is based on the interests in learning the language, to associate or to socialize with the people who speak the language, and the purpose or intention to participate or to integrate the second language using the same language in that community. However, it sometimes involves emotion or affective factors a great deal. On the other hand, the instrumental motivation involves the concepts of purely practical value in learning the foreign/second language in order to increase learners' careers or business opportunities, giving them more prestige and power, accessing scientific and technical information, or just passing a course of their study in school.

In general, motivation is broadly classified into two main categories of extrinsic motivation and intrinsic motivation. Extrinsic motivation refers to a desire to get a reward or to avoid punishment. It emphasizes the external need to persuade students to take part in learning activities such as homework, grade, or doing something to please teachers (Arnold, 2000). Both integrative and instrumental motivations are also grouped under the branch of the extrinsic motivation (Harmer, 1991). Extrinsic motivation is based on external outcomes such as rewards or punishments. This type of motivation could bring a negative impact on the students. The reason is that with the extrinsic motivation, students do not learn with their strong intention or they learn because they are pushed by the interest in the rewards or by the punishment they would recieve. When a student is learning because he/she is promised rewards or wants rewards, there will be a high motivation to attend classes, to learn, and to achieve the goal that is set. However, when these rewards are taken away, or sometimes when there are no punishments, the student will not be interested in coming to class to learn the language any longer.

Intrinsic motivation refers to learning having its own reward (Arnold, 2000). It means that the students are willingly and voluntarily (not compulsorily) trying to learn what they think has worth or is important to them. The students with intrinsic motivation will have the internal desire to learn, and they do not have the needs for external outcomes. There are also no negative impacts to the students who have the intrinsic motivation. In addition, the intrinsic motivation pushes the students to learn without any rewards, because their needs are innate, come from inside, or depend on their own will. Lightbown and Spada (1999) mentioned that teachers do not have much effects on students' intrinsic motivation because the students are from different backgrounds, and the only way to motivate students is to make the classroom a supportive environment. 


\section{The Importance of Motivation in a Foreign Language Learning}

Many previous pieces of research show that motivation plays an important role in the success or failure in learning a language in general, and in learning a language in particular. Spolsky (1990) stated that motivated students are likely to learn more quickly than students who are less motivated. In a specific learning situation, students who are less motivated are likely to lose their attention, to misbehave, and to cause discipline problems. On the contrary, students who are more highly motivated will participate actively and pay more attention to a certain learning task or activity.

Together with engagement, motivation is viewed in the literature as very important for enhanced learning outcomes of all students (Woolfolk \& Margetts, 2007). Motivation is seen as a pre-requisite and a necessary element for student engagement in learning. Student engagement in learning is not only an end in itself, but it is also a means to the end of students achieving sound academic outcomes (Ryan \& Deci, 2009). This is important because authentic engagement may lead to higher academic achievement throughout student life (Zyngier, 2008). If educators want to know and resolve the young students' issues and to make schools engaging places, then they actually have to listen to what students are saying about their classes and teachers (Mitra \& Serriere, 2012).

\section{Factors that Affect Motivation in a Foreign Language Learning}

Harmer (1991) considered the following four factors that can be dangerous to the students' motivation in language learning. The first factor is the physical condition of the classroom. The physical condition means the atmosphere in the class. For example, if the students have to study in a bad lighting classroom, an overcrowded class with too many students, have to look at the small board, or have to study in an unpleasant and smelly classroom, they can lose their motivation or their motivation in learning will be lowered. The second factor is the teaching methodology. The method of teaching which refers to the way students are taught by teachers must affect their motivation. Whenever the students feel bored with the teachers' method, their motivation would likely be lost or gradually decreased as Harmer (1991) said: "If the students lose the confidence in the teaching method of teachers, they will become demotivated." The third factor that affects the motivation of the students in a language learning is the teachers. The teachers are considered as the most powerful variable of motivation, but they also can become a major part in demotivating the students. Lastly, the fourth factor that affects the motivation of students in a language learning is the success in learning. The success refers to the appropriate level of challenge designed by the teachers. If the difficulty of work or learning activity is too high or too low, it can lead students to a demotivated situation in learning. As Harmer (1991) pointed out 
that giving high challenge activities may have a negative effect on motivation. Students can also equally be demotivated by a low level of challenge.

In addition, in the Krashen's affective filter hypothesis, the emotional states such as tiredness, depression, boredom, etc. can obstruct the learning process of the students. Furthermore, anxiety becomes a factor that influences the effective filter. Low anxiety is more helpful for second language acquisition (Krashen, 1988). This means that students' anxiety can affect their motivation. According to Krashen, there are three effective variables that interact with the affective filter which include: (a) Motivation which is beneficial for language acquisition, (b) Self-confidence which is also useful for acquisition, and (c) Anxiety which is good in the case where it is at a low level (Krashen, 1988).

\section{Relevant Research}

There are many different pieces of research in the past related to the motivation in a foreign/second language learning. The findings of most of these researches were consistent with the work of Gardner and Lambert (1972) which suggested that a person's need for studying a foreign/second language is for the ability to socialize with the target learning language community or integrative motivation, and for the ability to gain knowledge and skills applied from the target learning language or instrumental motivation.

For example, Hedge (2000) conducted a study that investigated the motivation of 20 Japanese students who were studying English. The findings of this study indicated that the most common reasons for studying English as a foreign/second language was for communicating with foreigners, finding employment in a high profile career, processing international information, and for understanding other cultures, etc.

Siriluck and Sirithip (2004) also conducted a study about the relationship between motivation and proficiency in English learning of undergraduate students. The study indicated clearly that high English proficiency students are more integratively motivated than low English proficiency students. However, there was no significant difference in the level of instrumental motivation between the two groups of students. Moreover, the study also showed that high English proficiency students are more motivated than low English proficiency students with low English achievement.

\section{Research Methodology \\ Participants}

The participants of the study were 371 students (first-year \& secondyear undergraduate students). These students belong to the undergraduate program of Information Technology (Faculty of Information Technology, 
VNU-UET). They attend the general English courses which are compulsory courses for all students at VNU-UET.

\section{Research Instrument}

The instrument for this study is a paper \& pencil questionnaire with 36 different items. The 30 main items of the questionnaire were designed using a 6-point Likert scale which was adopted from the original 7-point Likert scale format of Gardner’s Attitude/Motivation Test Battery (AMTB). It ranged from 'Strongly disagree' to 'Strongly agree'. The 30 main items are statements used to gather information on participants' motivation in English learning as a foreign language (Part 1). The first 13 items demonstrate the integrative motivation (items 1-13), and 17 items (items 14-30) present the instrumental motivation. The other items are about the private information of the participants (the general demographic information, the time of learning English, the parental speaking ability, and language skills (Part 2).

\section{Data Collection and Analysis}

The questionnaires were distributed to the students during their English class with clear instructions and explanation for filling out the questionnaires from their English teachers. The questionnaires were then collected upon completion. Then the information on the questionnaires was put into an Excel file or SPPS file.

The data and information gathered from the questionnaires were summarized and analyzed by using statistical tools such as SPSS to answer research questions. A 6-point Likert scale was used to measure the level and type of students' learning motivation. The level of English learning motivation was classified based on the following criteria in Table 1 .

Table 1. Level of English learning motivation

\begin{tabular}{ll}
\hline Mean Range & Level of Motivation \\
\hline $4.01-6.00$ & High \\
$2.01-4.00$ & Moderate \\
$1.00-2.00$ & Low \\
\hline
\end{tabular}

\section{Findings}

\section{General Information about Participants}

The questionnaire was administered in the spring of 2018. All participants $(\mathrm{N}=371)$ were the first-year and second-year students who were enrolled in autumn of 2016 and 2017 at VNU-UET. Vietnamese is their first language and English was introduced to them as a foreign language from Grade 3 or Grade 5 at primary school. The participants were either in the first year (50.1\%) or in the second year of university (49.9\%) (Table 2). Therefore, 
there is a very small difference between the number of students in the first year and in the second year.

Table 2. The school year of participants

\begin{tabular}{llllll}
\hline & & Frequency & Percent & Valid Percent & Cumulative Percent \\
\hline Valid & first year & 186 & 50.1 & 50.1 & 50.1 \\
& second year & 185 & 49.9 & 49.9 & 100.0 \\
\cline { 2 - 5 } & Total & 371 & 100.0 & 100.0 &
\end{tabular}

Table 3 below reflects the gender of the respondents: males (58.5\%) and females (41.5\%). This imbalance is due to the fact that, in general, more male students apply to study technical programs than female students. The information technology programs at VNU-UET usually attracts more male students than female students.

Table 3. Gender of participants

\begin{tabular}{llllll}
\hline & & Frequency & Percent & Valid Percent & Cumulative Percent \\
\hline \multirow{2}{*}{ Valid } & male & 217 & 58.5 & 58.5 & 58.5 \\
& female & 154 & 41.5 & 41.5 & 100.0 \\
\cline { 2 - 6 } & Total & 371 & 100.0 & 100.0 &
\end{tabular}

\section{Motivation}

\section{Integrative Motivation}

As mentioned above, the integrative motivation in foreign/second language learning was defined as the desire to be a part of recognized or important members of the community or the society that speaks the language. Table 4 shows the level of integrative motivation of the participants in the study.

Table 4. Integrative motivation

\begin{tabular}{llll}
\hline Content of item & Mean & S.D & $\begin{array}{l}\text { Level } \\
\text { motivation }\end{array}$ \\
\hline $\begin{array}{l}\text { 1. Learning E makes me understand E-books, movies, pop music, etc. } \\
\text { 2. Learning E makes me better understand and appreciate the ways of life of } \\
\text { native E speakers. }\end{array}$ & 5.15 & 0.402 & High \\
3. Learning E enables me to keep in touch with foreign friends. & 42 & 0.565 & High \\
4. By learning E I can discuss interesting topics with people from other cultural & 5.55 & 0.501 & High \\
backgrounds. & 5.03 & 0.377 & High \\
5. Learning E helps me convey my knowledge \& information to other people. & 4.39 & 0.492 & High \\
6. Learning E helps me participate freely in academic, social, and professional & 5.08 & 0.327 & High \\
activities among other cultural groups. & & & \\
7. Learning E helps me understand and appreciate arts \& literature in E speaking & 4.61 & 0.492 & High \\
cultures. & 5.01 & 0.431 & High \\
8. Learning E helps me be more confident and comfortable. & 5.15 & 0.402 & High \\
9. Learning E helps me enjoy traveling to foreign countries. & 4.72 & 0.512 & High \\
10. Learning E helps me become an open-minded and sociable person. & 4.58 & 0.497 & High \\
11. Learning E helps me have more friends. & 5.07 & 0.308 & High \\
12. Learning E helps me integrate more easily into E speaking communities. & & &
\end{tabular}


13. Learning E enables me to communicate easily with others online.

Mean of Measure

4.30 $\quad 0.490 \quad$ High

(Note: $E=$ English; S.D = Standard Deviation)

From Table 4, we can see that the integrative motivation of the participants in the study is rather high with the mean for the whole measure of 4.79. The mean for items in the measure is ranging from 4.30 to 5.15. The item 1 and 9 show the highest mean score among the items of the measure (5.15), while item 13 show the lowest mean score among other items (4.30).

\section{Instrumental Motivation}

Once again, the instrumental motivation involves the concepts of purely practical value in learning the foreign/second language in order to increase learners' careers or business opportunities, giving them more prestige and power, accessing scientific and technical information, or just passing a course of their study in school. Table 5 shows the level of instrumental motivation of the participants in the study.

Table 5. Instrumental motivation

\begin{tabular}{|c|c|c|c|}
\hline Content of item & Mean & S.D & $\begin{array}{l}\text { Level of } \\
\text { motivation }\end{array}$ \\
\hline 14. Learning $\mathrm{E}$ is important because I need it for my career in the future. & 5.49 & 0.531 & High \\
\hline 15. Learning E is important because it will help me to learn new things. & 5.45 & 0.529 & High \\
\hline $\begin{array}{l}\text { 16. Learning } \mathrm{E} \text { is important because it will help me get a good job in } \\
\text { multinational corporations. }\end{array}$ & 4.51 & 0.557 & High \\
\hline $\begin{array}{l}\text { 17. Learning } E \text { is important because I can get a lot of useful information for my } \\
\text { work in the future. }\end{array}$ & 5.38 & 0.489 & High \\
\hline $\begin{array}{l}\text { 18. Learning } \mathrm{E} \text { is important because it will help me have opportunities to get a } \\
\text { good job abroad. }\end{array}$ & 4.37 & 0.514 & High \\
\hline $\begin{array}{l}\text { 19. Learning } E \text { is important because it will help me have a chance to study } \\
\text { abroad. }\end{array}$ & 4.41 & 0.523 & High \\
\hline 20. I try my best to learn E so I can gain maximum proficiency. & 5.08 & 0.405 & High \\
\hline 21. I mainly focus on using $\mathrm{E}$ for class assignments \& exams. & 5.17 & 0.507 & High \\
\hline 22. I am interested in reading only E-textbooks in my university study. & 5.20 & 0.551 & High \\
\hline 23. I am not interested in reading E-newspapers, magazines etc. & 4.24 & 0.430 & High \\
\hline 24. I focus more on furthering my higher education than on learning $E$ language. & 4.70 & 0.490 & High \\
\hline 25. I focus more on earning a university degree than on learning E language. & 5.42 & 0.552 & High \\
\hline 26. I focus more on getting a good job than on learning E language. & 5.42 & 0.577 & High \\
\hline 27. Learning E helps me become a knowledgeable and skillful person. & 5.01 & 0.316 & High \\
\hline 28. Learning E helps me become an educated person. & 5.08 & 0.280 & High \\
\hline $\begin{array}{l}\text { 29. Being proficient in } \mathrm{E} \text { can lead to being more successful and achievable in } \\
\text { my life. }\end{array}$ & 5.13 & 0.335 & High \\
\hline 30. Being proficient in E makes other people respect me more. & 5.28 & 0.453 & High \\
\hline Mean of measure & 5.02 & 0.152 & High \\
\hline
\end{tabular}

(Note: $E=$ English $;$ S.D = Standard Deviation $)$ 
In the same pattern as integrative motivation, from Table 5, we also can see that the instrumental motivation of the participants in the study is quite high with the mean for the whole measure of 5.02. The mean for items in the measure is ranging from 4.24 to 5.49 . The item 14 and 15 show the highest mean scores among the items of the measure (5.49 and 5.45, respectively), while item 23 show the lowest mean score among other items (4.24).

From Table 4 and Table 5, we can see that there is a difference between the mean of the integrative motivation and instrumental motivation. The mean score of instrumental motivation is higher than the mean score of the integrative motivation (5.02 compared to 4.79). In order to test the difference between the mean of the integrative motivation and the instrumental motivation, we used the Paired-Samples T-Test to compare the mean of two paired samples (variables: the mean of the instrumental motivation instrmean and the mean of integrative motivation - integmean).

Table 6. Paired Samples Statistics

\begin{tabular}{|c|c|c|c|c|c|}
\hline & & Mean & $\mathrm{N}$ & $\begin{array}{l}\text { Std. } \\
\text { Deviation }\end{array}$ & $\begin{array}{l}\text { Std. } \\
\text { Mean }\end{array}$ \\
\hline \multirow[t]{2}{*}{ Pair 1} & Instrmean & 5.0207 & 371 & .15246 & .01809 \\
\hline & Integmean & 4.7974 & 371 & .22605 & .02683 \\
\hline
\end{tabular}

Table 7. Paired Samples T-Test

\begin{tabular}{|c|c|c|c|c|c|c|c|c|}
\hline \multicolumn{6}{|c|}{ Paired Differences } & \multirow{3}{*}{$\mathrm{T}$} & \multirow{3}{*}{$\mathrm{df}$} & \multirow{3}{*}{$\begin{array}{l}\text { Sig. } \\
\text { (2-tailed) }\end{array}$} \\
\hline & \multirow[t]{2}{*}{ Mean } & \multirow{2}{*}{$\begin{array}{l}\text { Std. } \\
\text { Deviatio } \\
\mathrm{n}\end{array}$} & \multirow{2}{*}{$\begin{array}{l}\text { Std. } \\
\text { Error } \\
\text { Mean }\end{array}$} & \multicolumn{2}{|c|}{$\begin{array}{l}\text { 95\% Confidence Interval } \\
\text { of the Difference }\end{array}$} & & & \\
\hline & & & & Lower & Upper & & & \\
\hline $\begin{array}{l}\text { Pair } 1 \text { Instrmean } \\
\text { Integmean }\end{array}$ & -.22331 & .21994 & .02610 & .17125 & .27537 & 8.555 & 370 & .000 \\
\hline
\end{tabular}

The Paired Samples Statistics table (Table 6) shows the mean of the instrumental motivation $=5.0207$ and the mean of the integrative motivation $=4.7974$. The Paired Samples Test table (Table 7) shows the mean $=0.22331$, $\mathrm{t}=8.555$, $\mathrm{df}=370$ and the Sig. (2-tailed) level $=0.000(<\mathrm{p}=0.05)$. So we can conclude that there is an overall statistically significant difference between the 2 means of related variables (the mean of the instrumental motivation instrmean and the mean of the integrative motivation - integmean). From the values of mean, we can conclude that the level of the instrumental motivation is higher than the level of the integrative motivation in the study. This conclusion is contradictory with the study of Alshaar organized in Kuwait where the mean score for the integrative motivation was higher than that for the instrumental motivation (Alshaar, 1997). In other words, the students' integrative motivation is significantly stronger than their instrumental motivation. However, our findings of the difference between the mean of the 
instrumental motivation and the mean of integrative motivation are consistent with the findings of Ratanawalee's study about motivation in English language learning of the first-year undergraduate students at Sirindhorn International Institute of Technology, Thammasat University, Thailand. Ratanawalee also concluded that the mean score of instrumental motivation is higher than the mean score of the integrative motivation (Ratanawalee, 2012).

\section{Some Factors that Influence the Motivation in a Foreign Language Learning}

Gender

Alshaar (1997) in his study stated that female students do not have more positive attitudes towards learning English than male students. Gardner (1985) considered attitudes as components of motivation in language learning and according to him, motivation refers to the combination of effort, the desire to achieve the goal of learning the language, and favorable attitudes towards learning the language. Therefore, do female students have higher mean scores in motivation towards learning English than male students?

From the data gathered in the study, female students had higher mean scores in the integrative motivation towards learning English than male students (4.7813 versus 4.7613 respectively). In fact, the IndependentSamples T-Test indicated that the difference was not significant $(\mathrm{t}=1.466$, Sig. $(2$-tailed $)=0.148)$. Therefore, females do not have more integrative motivation towards learning English than males. Although this finding is contradictory to male students having higher mean scores in the instrumental motivation towards learning English than female students (5.0226 versus 5.0184 respectively). In fact, the Independents-Samples T-Test indicated that the difference was not significant $(t=0.115$, Sig. (2-tailed) $=0.909$ ). Therefore, males do not have more instrumental motivation towards learning English than females. We can conclude that gender has no clear effects on the motivation in English language learning.

\section{The Different School Year}

The time which the students spent at the university would be a factor that affects the students' motivation in English learning as a foreign language. In order to find the influence of the time students spent at the university on motivation, we used the Independent-Samples T-Test to test the difference in the mean score of motivation between the first year students and the second year students.

Analyzing the data gathered in the study, we could see that the second year students had higher mean scores in the integrative motivation towards learning English than the first year students (4.9099 and 4.6880 respectively). The Independent-Samples T-Test indicated that the difference was significant 
$(\mathrm{t}=0.4691$, Sig. $(2$-tailed $)=0.000)$. Therefore, the second year students do have more integrative motivation towards learning English than the first year students. For the instrumental motivation, we could also see that second-year students had higher mean scores in the instrumental motivation towards learning English than the first year students (5.0807 and 4.9624) respectively. The Independent-Samples T-Test also indicated that the difference was significant $(\mathrm{t}=0.3512$, Sig. (2-tailed $)=0.001)$. In general, the second year students have more motivation (both integrative and instrumental) in English learning than the first year students. This difference is as a result of indirect influences on students from learning environment, teaching methodology, or the changes in attitudes toward English learning.

\section{The Time Learning English}

In order to see how the time the students have been learning English affects their motivation in English language learning, we asked the students in the study about the time they have been learning. The time was divided into 4 groups: 1-3 years, 4-6 years, 7-9 years, and 10 years or more. In the study, all the students belong to group 3 (7-9 years) and group 4 (10 years or more) respectively. This means that all the students started learning English at least since Grade 6.

From the data collected and analyzed, the students in group 4 had higher mean scores in the general motivation (combination between the integrative and instrumental motivation) towards learning English than the students in group 3 (4.9650 versus 4.9049 respectively). In fact, the Independent-Samples T-Test indicated that the difference was not significant $(t=1.358$, Sig. $(2$-tailed $)=0.184)$. Therefore, the students with longer time in learning English do not have more general motivation towards learning English than the students with shorter time.

\section{The Parental Ability in Speaking English}

In this study, we wanted to know how the parental ability in speaking English influences the students' motivation in English learning. Therefore, in the questionnaire, the students had to provide information about their parents' ability in speaking English.

From data collected, in the total of 371 students that participated in the study, 61 mothers and 65 fathers can speak English. In both cases, the mother or the father who can speak English has a positive influence on the students' motivation in English learning. The students whose mothers can speak English had higher mean scores of the general motivation than students who have mothers that cannot speak English (5.0513 and 4.8245 respectively). The Independent-Samples T-Test also indicated that the difference was significant $(\mathrm{t}=8.544$, Sig. $(2$-tailed $)=0.000)$. In this case, the mother's ability in speaking 
English has a positive influence on student's motivation in English learning. It is in the same pattern for students who have fathers that can speak English. The students who have fathers that can speak English had higher mean scores of the general motivation than students who have fathers that cannot speak English (5.0003 and 4.8489 respectively). The Independent-Samples T-Test also indicated that the difference was significant $(\mathrm{t}=4.726$, Sig. $(2$-tailed $)=$ $0.000)$.

The findings of the influence of parents' ability on students' motivation in English learning are consistent with the research by Hamidah and her colleagues about parental influence on students' motivation in English learning. According to Hamidah, parents are the first teachers of a student and they take responsibility for their education. They are also role models for attitudes and behaviors that could assist in future success, as well as the development of English interests and activities. Students often learn attitudes, cultural morals, and values from their parents (Hamidah et al., 2017).

\section{The Most Difficult Skill in English Learning}

In learning English, students always try to develop all four language skills that are important for daily communication which include: listening, speaking, reading, and writing. In order to know the difficulties that the students usually face related to four different language skills during the process of learning English, we asked the students to consider which language skill is the most difficult.

Table 7. The most difficult language skill

\begin{tabular}{lll}
\hline Language skills & Frequency & Percent \\
\hline Speaking & 188 & 50.7 \\
Listening & 145 & 39.1 \\
Reading & 23 & 6.2 \\
Writing & 15 & 4.0 \\
\hline Total & 371 & 100.0 \\
\hline
\end{tabular}

Table 7 shows the opinions of the students about the most difficult language skill. Speaking skill was considered the most difficult language skill by the students (50.7\%). Listening skill was the second most difficult language skill with $39.1 \%$ of students that participated in the study. This finding is contradictory with the study of Ratanawalee where the students considered writing as the cause of most problems (47\%), and listening makes the least problems to the students (10\%) (Ratanawalee, 2012).

Furthermore, knowing the problems that students would face during the learning process is very important. It would help the curriculum and instruction designers, and the teachers. It would also provide guidelines to 
improve the quality of teaching and learning, and especially improve the motivation of the students in English language learning.

\section{Discussion and Recommendation}

In general, from the study, the students are highly motivated to learn English as a foreign language. This finding answered the research question about the level of the students' motivation. Within the scope of the study, it only focused on two types of motivation: integrative and instrumental. Based on the comparison and assessment, we found that the students in the study are more instrumentally motivated to learn English than integrative motivation. The students' tendency towards the instrumental motivation could be explained by the focus of the students on getting a good job that needs proficiency in English or getting a certificate of English to pass through the VNU-UET foreign language requirements.

Within the factors studied (gender, the school year, the time learning English, and the parental ability in speaking English) that might influence the students' motivation in English language learning, only the different school year and the parental ability in speaking English have significant influences on the students' motivation. Specifically, the second year students have greater motivation in English language learning than the first year students. The second-year students have spent more time in the university learning environment than the first year students. This has led to the changes in attitudes towards English learning. This is the reason for explaining the difference of motivation in English language learning. The students who have parents that can speak English also have a higher level of motivation in English language learning. The importance of parents on attitudes, motivation, and behaviors in learning, in general, is consistent with many previous studies.

Speaking and listening skills were the most troublesome to the students that participated in the study. These two language skills are very important to communicate with other people, therefore more attention should be given to building the training programs, curriculums, teaching methodology, and the study resources to improve these language skills.

Based on the findings of this study, the results are unique for only particular students that participated in the study. The students have a high level of motivation in both instrumental and integrative aspects, whereas, instrumental motivation is significantly higher than the integrative motivation. Furthermore, the study with other students in different universities with largely different education context would produce significantly different results. Therefore, future studies should include more different universities to improve the quality of the study.

The data of the study was collected from only 371 students of the firstyear and the second-year within a strict time limit. It is recommended that a 
larger sample size with a longer time frame should be extended to increase the degree of generalization of the study, in order to make the findings more valid and reliable. This study, however, does not examine motivation in English language learning of students in the third and fourth year. It is recommended that more variety of participants should be included.

In summary, this study was conducted to provide some insights into the level and type of motivation in English language learning with the participants of the first and second-year students at VNU-UET. The study provides useful knowledge and information about motivation and factors that influences the students' motivation in English learning. These value knowledge and information would help to improve the students' motivation, and ultimately improve the students’ proficiency in English.

\section{References:}

1. Alshaar, B. E. (1997). Attitudes and motivation of second language learners in Kuwait. Retrospective Theses and Dissertations. 277..

2. Arnold, J. (2000). Affect in language learning. Cambridge: Cambridge University Press.

3. Brown, H. (2000). Principles of language learning and teaching. New Jersey: Prentice Hall.

4. Dörnyei, Z. (2001). Motivational strategies in the language classroom. Cambridge, UK: Cambridge University Press.

5. Ellis, R. (1986). Understanding second language acquisition. Oxford: Oxford University Press.

6. Ellis, R. (1994). The study of second language acquisition. Oxford: Oxford University Press.

7. Gardner, R.C. \& Lambert, W.E. (1972). Attitude and Motivation in Second Language Learning. Rowley, MA: Newbury House.

8. Gardner, R. C. (1983). Learning another language: a true social psychological experiment. Journal of language and social psychology, 2, $219-240$.

9. Gardner, R.C. (1985). Social psychology and second language learning: The role of attitudes and motivation. London: Edward Arnold Publishers.

10. Gardner, R. C. (2006). The socio-educational mole of second language learning. Rowley, Massachusetts: Newbury House.

11. Hamidah, A. R., Azizah, R., Shah, R. A. W., Faizah, M. N., Wan, Z. W. Z., \& Mohd, A. B. (2017). Factors affecting motivation in language, Learning International Journal of Information and Education Technology, Vol. 7, No. 7.

12. Harmer, J. (1991). The practice of English language teaching. London: Longman. 
13. Krashen, S. (1988). Second language acquisition and second language learning. London: Prentice Hall International (UK).

14. Lightbown, P.M. \& Spada, N. (1999). How languages are learned? Oxford: Oxford University.

15. MacDonough, S. (1983). Psychology in foreign language learning. George, Allen\& Unwin: London.

16. Midraji, S. (2003). Effective factors and ESL. Learning. In C. Coombe, P. Davidson, \& D. Lloyd (Eds.). Proceedings of the 5th and 6th current trends in English language testing (pp. 19-32). Dubai, U.A.E: TESOL Arabia.

17. Mitra, D. L. \& Serriere, S. C. (2012). Student Voice in Elementary School Reform Examining Youth Development in Fifth Graders. American Educational Research Journal, 49(4), 743-774.

18. Parsons, R., Hinson, S., \& Brown, D. (2001). Educational psychology: practitioner - researcher models of teaching. University of Virginia: Wadsworth Thomson Learning.

19. Ratanawalee, W. (2012). A survey study of motivation in English language learning of first-year undergraduate students at Sirindhorn International Institute of Technology (SIIT), Thammasat University, Thailand.

20. Ryan, R. M. \& Deci, E. L. (2009). Promoting self-determined school engagement: Motivation, learning, and well-being. In K. R. Wentzel \& A. Wigfield (Eds.), Handbook of motivation at school. (pp. 171196). New York: Routledge

21. Saville-Troike, M. (2006). Introducing second language acquisition. New York: Cambridge University Press.

22. Siriluck, W. \& Sirithip, P. (2002). Integrative motivation, instrumental motivation, and English achievement among students in the Faculty of Arts. Unpublished master's thesis, School of Language and Communication. National Institute of Development Administration.

23. Spolsky, B. (1990). Conditions for second language learning. Hong Kong: Oxford University Press.

24. Woolfolk, A. \& Margetts, K. (2007). Educational psychology. NSW, Australia: Pearson. Prentice Hall.

25. Zyngier, D. (2008). (Re)conceptualizing student engagement: Doing education not doing time. Teaching and Teacher Education, 24, 1765-1776 